DOI: 10.20472/IAC.2019.047.016

NOEL PACKARD

University of Auckland, New Zealand

\title{
ALIENATING MARX(ISTS) FROM THE COLD WAR INTO SURVEILLANCE CAPITALISM
}

\begin{abstract}
:
Marx's Machine Age theory of capitalism ascribes a unique driving role for alienation and argues new modes of production emerge from past modes of production. Presently so-called surveillance capitalism is superseding Machine Age capitalism and distributing wealth unequally to a $1 \%$ global elite. There are debates about what alienation is at work in this changed epoch. Premised on Marx's idea that modes of production are born in the previous epoch along with the alienation that works with them, a hypothesis about how today's Internet enables both endless free speech, while inversely and simultaneously, enabling endless spying with impunity is presented here. The hypothesis is a conceptualization of alienation labeled as "known unknown." The adaption of the term "known unknown alienation" stems from the discourse in the film, "The Unknown Known" which highlights aspects of known unknown alienation, in the form of so-called national security experts who are mentally divided about what they can and can not know (or talk about) and also the divide between the expert and the taxpayer, who does not qualify to have access to the same information that the expert has. This personal internal contradiction and social alienation is compounded because Americans are proud of US constitutionally protected free speech rights (which according to The Citizens United Act allows corporations to be individuals); these contradictions help drive surveillance capitalism. The historical-comparative argument is: "Communist hunting" intelligence agents, scientists, and contractors, backed by neoliberal economists, built a military-industrial-complex that obligated them to both known and not know, or in the case of the CIA be "witting" of national security secrets, which alienated them from US constitutional free speech. Their alienation manifest in their interactive inventions - the Internet, pc and cell phone - devices that today dialectically give customers the ability to express free speech endlessly in electronic memory form, while inversely giving spies unlimited access to that speech with impunity. This process works in tandem: enabling appropriation of data for government surveillance and service fee payments for corporations.
\end{abstract}

\section{Keywords:}

alienation, Internet, neoliberal, Cold War, intelligence, surveillance, witting

JEL Classification: H54, H56, O33 


\section{Introduction}

Today digital/surveillance infrastructure helps enrich $1 \%$ of the population, enabling them to appropriate nearly half the world's wealth in less than half a life-time (Phillips 2018) and the same infrastructure enables telecommunications companies and intelligence agencies to appropriate endless electronic memory about customers (Zuboff 2019). There are debates about the alienation working in tandem with this powerful new appropriation. Alienation (2014) by Rahel Jaeggi, offers Frankfurt School theories about alienation in the digital age. German critical theory applied to the concept of alienation in a digital world is represented in this survey. Christian Fuchs critiques Alienation and states his epistemological assumption is, "Internet research is predominantly a positivist science that lacks grounding in social theory and tends not to reflect on the Internet's larger presuppositions in society." (Fuchs, 2016, p. 153) Both Alienation and Fuchs' article categorize forms of alienation and reification (Fuchs, 2016, Table 5.3). Fuchs book, Digital Labour and Karl Marx reiterates Marx's theory of alienation (Fuchs 2014, pp. 32-34; Marx 1978/1844, pp. 66-125) while Jaeggi's book ranges broadly over theories of alienation from thinkers such as: Butler, Dewey, Foucault, Frankfurt, Fromm, Goffman, Habermas, Hegel, Heidegger, Honneth, James, Marx, Mead, Nietzsche, Nussbaum, Rorty, Rosa, Rousseau, Sartre, Turkle and many more. The kinds of alienation Fuchs or Jaeggi conceptualize may exist and if so, wouldn't their roots be in the previous mode of production?

The hypothesis for known unknown alienation proposed here, offers a hypothetical example of alienation rooted in an earlier epoch, that today functions in tandem with appropriation in digital/surveillance capitalist economy. The hypothesis is: military-industrial-complex contracted employees, like the scientists, engineers and academics described by Norberg and O'Neill, in Transforming Computer Technology : Information Processing for the Pentagon, 1962-1989 (1996) often are witting about national security secrets and yet are suppose not to know them, a contradiction that fosters a kind of alienation, particularly in a country that boasts of constitutionally protected free speech. Although not based inside a military Research and Development $(R \& D)$ context, this contradiction is exemplified in the case of W. Eugene Groves and the Central Intelligence Agency (CIA), as detailed in the Introduction to Hugh Wilford's The Mighty Wurlitzer: How the CIA Played America (2008, pp. 3-7). Groves became president of the US National Student Association (NSA) in 1966, after having studied physics and winning a Rhodes Scholarship to Oxford. Upon assuming his responsibilities as president, the outgoing president informed Groves the NSA was a Central Intelligence Agency (CIA) front (or funded) organization, formed in the Cold War era to apprehend Communists and modeled on a Communist style under-cover front system. Groves had just been made officially "witting" (in CIA language) that the NSA was not congruent with its' official public association image. $\mathrm{He}$ was appalled; but he shouldered the secret for the sake of those un-witting. Within his tenure as president however, Groves confronted the CIA about his misgivings and even negotiated to release a press statement that would essentially "blow the cover" on the NSA relationship with the ClA. The press report was published in the New York Times in 1967 along with an advertisement for the Ramparts Magazine article that blew the cover on American Institutes for Research (AIR) work in Vietnam. Following after the press release, the New York Times went on to publish a series of reports about covert CIA front organizations. Wilford reports that after 
Groves completed his presidency of NSA instead of going on with his academic career, he "retreated into private life. "The world [has] los[t] its innocence." He told the NSA's 1967 congress. "I want to get out." (Wilford 2008, pp. 5)

For government employees and contractors who shoulder trade, corporate, job and national security secrets, free speech isn't always an option, or it is a dangerous option, as whistleblowers like Daniel Ellsberg, Edward Snowden or Bradley/Chelsea Manning have demonstrated (Greenwald 2014). People harboring national security, job, trade, political, corporate and even crime related secrets can't or don't always exercise free speech. So when other people do exercise free speech, to protest against national security, corporate, employer or government abuses, those who harbor secrets for employers may feel resentful or feel like they are missing out or are excluded or feel any number of feelings. Matter how justified the solidarity these contractors might feel towards a social movement such as the New Deal programs or an anti-war movement, once contracted to work in a national security oriented job, he or she is professionally bound to support the government's interests over and above the interests of those who may protest against the military and pay the taxes for it. That "known unknown" alienation between the military contractors and the taxpayers or concerned citizens, became manifest, I argue, in the scientists computerized and interactive inventions, the cell phone, the $\mathrm{pc}$ and the Internet. The inventors of these devices have dialectically delivered to us, through these devices, a mode of Internet communication, production and exchange that allows both unlimited free speech for those who wish to express it, which includes a multi billion dollar on-line pornography industry (Lane III, 2000, p. 293) and unlimited spying capability with impunity, for spies and the people they work for. Perhaps the military-industrial-contracted scientists and professors could not communicate in much depth very with their anti-war protestor students in the Cold War era (Bell \& Kristol 1968; Levine, 2018, pp. 70-1; Rosenfeld, 2013) but they created new ways to communicate for the next generation, complete with a new kind of alienation.

\section{Methodology}

Like an earlier publication about alienation, titled, "Habitual Interactive Estranged" (Packard 2018a) which imposes Marx's alienation theory (Marx, 1844/1978, pp. 70-93) on a contemporary context, this article is Marx inspired, historical comparative in method and adheres to Marx's idea that each new epoch is pregnant with the one that will forcefully replace it (Marx, 1867/1990 pp. 916, 928-9). This article is my own hypothesis imposed on US militaryindustrial-complex history, to explain a kind of alienation that Internet inventors experienced from knowing and also having to pretend not to know national security secrets. The inventors' hypothetical known unknown alienation became manifest into their inventions and today it functions in tandem with appropriation in a digital/surveillance production and exchange mode.

Historical facts below help explain how known unknown alienation is/was intertwined within the social relations of the military-industrial-complex and scientists who helped rationalize its operations and budget. The complex includes: Advanced Research Projects Agency (ARPA) which became Defense Advanced Research Projects Agency (DARPA) in 1958; within ARPA was the Information Processing Techniques Office (IPTO) which addressed and solved the problem of creating Internet communications across networks and much more (Norberg \& 
O'Neill 1996, p. 183-196); beyond ARPA were other contract R\&D organizations such as Special Operations Research Office (SORO); RAND, which contracted many Chicago School economists to US Operations and Research (OR) programs; major corporations like Boeing, Northrup, Booz Hamilton, IBM, Honeywell, Digital Equipment Corporation, Raytheon, General Electric (to name only a few) and a network of universities and labs, such as Lincoln Laboratory associated with MIT, Servomechanisms Laboratory, Bell Laboratory, the Research Laboratory of Electronics and the Aiken Computational Laboratory and universities across the country. DARPA was formed and funded to counter "the Communist threat" and its scientists and engineers pioneered development of the Internet (Jacobsen, 2015; Levine 2018; Norberg \& O’Neill,1996).

"Known unknown alienation" is a tentative label for the hypothetical alienation in the digital age, discussed here, and inspired by the film, The Unknown Known (2013). The film shows us an example of an official keeper of government secrets, Donald Rumsfeld, who likely has known unknown alienation, as he functioned within a vast bureaucracy that maintains secrets about what it does. Essentially we see a divide within the so-called national security expert (Rumsfeld) about what he can and can not know (or talk about) and a divide between the expert and the taxpayer, as represented by Morris and also the press reporters (featured in the Special Bonus section of the film) who seek answers to questions, but who do not qualify to have access to the same information that the expert has. This personal internal contradiction (inside the expert) and the social alienation (the divide between expert and the non-experts) is compounded by the fact that Americans are proud of US constitutionally protected free speech rights. And according to The Citizens United Act these rights allow corporations to be individuals. These contradictions drive our new surveillance capitalism. Following below is historical context that describes the some of the history of the vast bureaucracy of the military-industrial-complex, an environment, which in turn created the Advanced Research Project Agency (ARPA) and IPTO scientists along with the "national security expert" politician. Discourse between filmmaker Errol Morris and two-time Secretary of State Donald Rumsfeld in The Unknown Know is analyzed followed by a conclusion.

\section{Setting Context: the Cold War, National Security, ARPA and secrets}

1947 to 1950s Cold War: In 1947 Congress legislated the National Security Act, the largest military restructuring ever made by the US government. It created the Air Force and replaced the Office of Special Services (OSS) with the CIA. The FBI's authority to spy on Americans was reaffirmed by Harry Truman in 1946. The national Security Act gave introduced the US to ideology regarding "national security," which was defined in the White House. Postwar presidents claimed the power to define national security and to act, often in secret, to enforce it. The ability to act secretly bolstered the president's claim of authority and allowed administrations to engage in permanent intervention in politics at home and abroad in ways that were by design offensive to American values. As a result, a secret realm of government developed to watch and, and if necessary, disrupt political opponents at home and abroad (Halperin, M. H et. al. 1976, p.p. 5-6).

Communist purging in the name of national security began after the Russian Revolution in 1917 (Brinson 2004; Donner 1981; Murray 1955; Storrs 2013) and continued into the 1950s with the 
famous McCarthy hearings that interrogated Hollywood entertainment figures. Protecting secrets and national security became a media sensation when former State Department official Alger Hess was convicted of perjury and physicist Klaus Fuchs was apprehended in 1950 for passing nuclear secrets to the Soviets, leading to the discovery and execution of Ethel and Julius Rosenberg (Stone \& Kuznick, 2013, pp. 230-235). In 1956 Senator Joseph McCarthy was censured and investigations curtailed. To J.E. Hoover however, this appeared to be a setback on subversion control. Acting on his own, he began a secret $\mathrm{FBI}$ program called COINTELPRO to "disrupt, expose, discredit, and otherwise neutralize the United States Communist party and related organizations" (Halpern et. Al, 1976, p. 112; Stone \& Kuznick, 2013, pp. 235). COINTEPRO was used against Martin Luther King, John Lennon, anti-Vietnam War protestors and many others; a form of punishment for past political actions, without trail (Donner 1981, p. 20).

Subversion and keeping national security secrets became important concerns in the academy since the Pentagon was investing millions of dollars into basic research programs in universities across the country (Rohde 2013, p. 106-7). Chicago School sociologist Edward A. Shils authored a book about the subject of secrecy, titled The Torment of Secrecy: The Background and Consequences of American Policies (1956). The book is oriented against the abuses of the McCarthy hearings and towards an "equilibrium" theory of balancing privacy, publicity and secrecy in a free country. Shils grapples with the contradictions of justifying national security secrets in a free country that protects privacy, freedom and free speech. He defines secrecy as "privacy made compulsory" (Shils, 1956, p. 201). He takes a neoliberal position that government protects private industry and everyone is responsible for protecting national security, which may mean sacrificing personal privacy. Shils makes cryptic arguments about secrecy, publicity, restriction and overflow, control of communists, subversion and espionage. Shils' book foretells future debates regarding privacy protection laws or the impossibility of them; as taken up by lawyers like University of Chicago law professor Richard Posner. This exemplifies how the Chicago School approach spread beyond economics, into other disciplines (Emmett, 2011 pp.112-3). Sixty years later, Scott Horton's book Lords of Secrecy: The National Security Elite and America's Stealth Warfare (2015) confirms secrecy has corrupted the government and left Americans without power to regulate decisions by a power elite. Horton like Shils, calls for " a healthy balance among the needs for secrecy, privacy and publicity . . . "but a balance in favor of the public's right to know (Horton 2015, p. 202).

1958 to 90s the duo-rise of the military-industrial-complex and neo-liberalism: To maintain western power against the communist threat in post-WWII Europe, the US cultivated alliances with North Atlantic Treaty Alliance (NATO) countries, financed the Marshall Plan in war torn Europe and fostered a "containment" and cold war strategy towards Stalinist Russia (Stone \& Kuznick, 2012, pp. 209-213). Although the US won WWII, showing the world it had the atomic bomb, it immediately began preparing for war with the Soviets. After the Soviets launched Sputnik 1 and 2 in 1957 the US Congress wrote the Advanced Research Projects Agency (ARPA) now known as Defense Advanced Research Projects Agency (DARPA) into a 1958 Air Force appropriations bill with a $\$ 520$ million initial funding and a $\$ 2$ billion budget. ARPA facilitated research projects between military contractors, think tanks and universities. 
So began the "arms race" and the "military-industrial-complex," which former President Eisenhower considered an organized "set of powerful interest groups that threatened American democracy and sought new weapons regardless of the actual need" (Schlosser 2013, pp. 175$6,199)$. By all accounts the US taxpayers funded the world's most expensive R\&D for "command and control" programs aimed at enhancing human and machine capabilities for both weapons and communication systems. Comparing the DARPA to the IPTO budgets between 1963 and 1984 shows the IPTO funding at a fraction of the total DARPA budget but nevertheless in 1988 the budget for the new strategic computing program (sc) was at about \$226 million (Norberg \& O’Neill, 1996, pp. 22, Fig.1).

Post-WWII America capitalists and conservative politicians saw communist threats not only in war torn countries of Europe and in Russia, but also inside the US government and the academy. Cloaking themselves in anti-communist rhetoric (Brinson, 2004, p. 3) conservative businessmen, neoliberal economists and politicians expanded the military-industrial-complex and domestic counter-insurgency programs, enlisting the support of powerful political figures like President Ronald Reagan and Prime Minister of Britain, Margaret Thatcher, Nobel Prize winning neoliberal economists Friedrich A. Hayek and Milton Freidman and Paul Volcker, head of the US Federal Reserve. Just before the world wide depression of 2008 gutted the American economy, economist Harvey, Phillips and Sklair have argued the shift to neoliberalism has successfully marginalized planned or socialized economic programs across the world, while reestablishing, in the digital age, an elite class and huge global wealth inequality (Harvey 2005, p. 79; Phillips 2018; Sklair 2001). It appears neoliberalism is as much a weapon against the socalled communist threat, as contract defense weapon development is, since they are intertwined through the social relations of the military-industrial-complex.

Over the decades neoliberal victories usurped many of the gains of the New Deal including Keynesian economics (Morgan and Rutherford, 1998; Leeson 2000, 2008). Communications technology was developed for war in R \& D programs like ARPA, which built the Internet. Once the Internet became fully operational it was rapidly and quietly sold off to private companies. Levine reports on how Stephen Wolff helped privatized the Internet in Surveillance Valley: The Secret Military History of the Internet (2018). Essentially the National Science Foundation (NSF) an educational program, had a special "Net backbone" infrastructure built for academic purposes, which it allowed IBM and $\mathrm{MCl}$ to use for private business purposes, without letting either the public or other market competitors know about the deal (Levine, 2018, p. 123). The Internet, born from taxpayer-funded research, was privatized in the midst of Ronald Reagan's Presidency - the heyday of neoliberalism, when everything was being de-regulated and privatized. In 1996 President Clinton signed the Telecommunications Act of 1996 (which left corporations in ownership of all the media). According to Zuboff, being able to regulate the industry without much government oversight has liberated the GAFA (Google, Apple, Facebook, Amazon) and telecom industries to embrace what law professor and author of the Black Box Society Frank Pasquale describes as "free speech fundamentalism" with a "cyber-libertarian" ideology. Zuboff writes:

Their legal teams aggressively assert First Amendment principles

To fend off any form of oversight or externally imposed constraints 
That either limit the content on their platforms or the "algorithmic

orderings of information" produced by their machine operations.

As one attorney who has represented many of the leading

Surveillance capitalists puts it, "The lawyers working for these

Companies have business reasons for supporting free expression.

Indeed, all of these companies talk about their businesses in the

language of free speech. (Zuboff, 2019, p. 109)

Today six of the richest people in the world, Bill Gates, Carlos Slim Helu, Jeff Bezos, Mark Zuckerman, Larry Ellison, and Warren Buffet reap profits from telecommunication companies that owe their technological origination to taxpayer paid-for-research conducted in government funded OR programs. Much of that wealth redistribution has happened since the advent of digital technology. The military-industrial-complex distributes wealth upwards (Phillips 2018, pp. 221-262; Sklair 2001) and appropriates customers' personal data (Zuboff 2019). It appears that this new digital mode of production is very effective at appropriating wealth so the alienation that works with it must be very effective as well.

\section{Post 9/11; the Patriot Act; Outsourced intelligence gathering and whistleblowers}

The crisis of $9 / 11$ gave the government a new enemy to displace the "Communist threat", namely the "terrorist" and "the leaker" - those who hack information systems and leak national security secrets. The PATRIOT Act was passed, allowing third party tele-communications industries to hunt for terrorists in electronic meta-data (Harris, 2010, 2005; Shorrock 2008). Whistleblowers like Julian Assange, Bradley/Chelsea Manning, Edward Snowden and others, warned the world that the US military-industrial-complex had expanded into a network of private tele-communications companies that worked with government intelligence gathering agencies to spy on people's electronic communications the world over (Greenwald, 2014).

The mode of production had shifted from mechanical to electronic and digital in secretive ways, both in production and in the privatization of the Internet. Scot Horton, reporting on the problematic rise of state secrecy explains that in creating a national security state the US also created an new kind of elite, or "national security experts inside a vast bureaucratic apparatus" and it pays upwards of $\$ 11.63$ billion a year for maintaining classified, un-accessible, documents (Horton, 2015, pp. 20, 177). Some of those experts externalized those secrets and became whistleblowers. The rise of whistleblowers corresponds with an increase in classified government documents. As more government documents became classified the divide between those who know (and don't know) secrets and those who pay for the national security but are not privy to knowing how their taxes are spent, widens. This contradiction presents an entry point for introducing discussion about the discourse between Errol Morris and Donald Rumsfeld in The Unknown Known film. Donald Rumsfeld is no stranger to the military-industrial-complex, having served twice as the United States Secretary of Defense and as architect of the Iraq War. Rumsfeld exemplifies a national security expert and essentially a keeper of official secrets. Errol Morris, an acclaimed filmmaker of award winning political documentaries, such as the Fog of 
War is no stranger to promoting free speech and inquiry. Here the national security expert and official keeper of secrets

\section{Donald Rumsfeld, Errol Morris and The Unknown Known}

Filmmaker Errol Morris interviewed Rumsfeld for this movie about Rumsfeld, The Unknown Known (2013). In his long tenure with the government Rumsfeld had always dictated what he calls "working documents" which chronicled his daily governmental work. At the opening of the movie Morris asks Rumsfeld how many documents he dictated and Rumsfeld says, " 20,000 in the last six years in the Pentagon . . . there have to be millions." Morris had Rumsfeld read some of them. Morris wondered if Rumsfeld had ever actually read his memos since he signed legislation that caused massive human rights violations against Iraqi detainees. Morris focused his attention on Rumsfeld's evasiveness. In particular he focused on Rumsfeld's ideas about the "known and the unknown"; "the absence of evidence is not evidence of absence"; and "failure of imagination" which Rumsfeld writes about in the opening pages of his biography, titled Donald Rumsfeld: Known and Unknown (2011). Morris did his own research about these phrases and added it to the movie as a special bonus feature. The special attention given to the topic of "The Unknown Known" issue highlights what I think is the cause of known unknown alienation, essentially a divide within national security experts about what they can and can not know (or talk about) and a divide between the expert and the taxpayer who does not qualify to have access to the same information that the expert has.

The Special Bonus, titled, Four-Part Op-ed "The Certainty of Donald Rumsfeld" by Errol Morris consists of: Part 1: Three Reporters; Part 2: The Known and the Unknown; Part 3: A Failure of Imagination and Part 4: Absence of Evidence Isn't Evidence of Absence.

Part I is about Rumsfeld's first public use of the known and unknown terminology at a Pentagon news conference on Febuary12, 2002, five months after 9/11 and a year before the invasion of Iraq. Morris reports on the press briefing and interviews the three reporters who asked Rumsfeld for evidence regarding weapons of mass destruction (WMD) in Iraq. Here is the question from the NBC Pentagon Correspondent, Jim Miklaszewski, at the press briefing that prompts Rumsfeld to define the "unknown known":

JIM MIKLASZEWSKI: In regard to Iraq weapons of mass destruction and terrorists, is there any evidence to indicate that Iraq has attempted to or is willing to supply terrorists with weapons of mass destruction? Because there are reports that there is no evidence of a direct link between Baghdad and some of these terrorist organizations.

DONALD RUMSFELD: Reports that say that something hasn't happened are always interesting to me, because as we know, there are known knowns; that is to say we know there are some things we know we know. We also know there are known unknowns; that is to say we know there are some things we don't know. But there are also unknown unknowns - the ones we don't know we don't know. And if one looks throughout the history of our country and other free countries, it is the later category that tend to be the difficult one. (Morris, $2013 \mathrm{~b}$ ) 
In Part 2 "The Known and the Unknown" Morris gives us his own description of these phrases and then he quotes from Rumsfeld's biography. He writes;

The known known, the known unknown and the unknown unknown seemingly have straightforward interpretations... Things we know we know- like the name of the president of the United States. .

And things we know we don't know - like the exact population of Kathmandu.. . . Things we know we don't know but we can look them up, say on Wikipedia. . . Or things that we know we don't but need to be investigated. . It goes on and on and on. It begs us to answer the question what does it mean to know something? Or to know that we know something? Or to know that we don't known something? Doesn't it depend on evidence? As Rumsfeld tells the story, the known and the unknown are linked (see also aforementioned Feb 12 news conference) with the absence not the presence of evidence. Rumsfeld writes in his memoir:

The idea of known and unknown unknowns recognizes that the information those in responsibility in government, as well as in other human endeavors, have at their disposal is almost always incomplete. It emphasizes the importance of intellectual humility, a valuable attribute in decision making and in formulating strategy. It is difficult to accept - to know-that there may be important unknowns. The best strategists try to imagine and consider the possible, even if it seems unlikely. They are then more likely to be prepared and agile enough to adjust course if and when new and surprising information requires it - when things that were previously unknown become known.

I also encountered this concept in Thomas Schelling's forward to Roberta Wohlsetter's book Pearl Harbor: Warning and Decision, in which Schelling identified a "poverty of expectations" as the primary explanation for America's inability to anticipate and thwart the Japanese attack on Hawaii. Schelling's message was as clear as it was prescient: We need to prepare for the likelihood that we would be attacked by an unanticipated foe in ways that we might not imagine." (Rumsfeld, 2011, p. xiv)

Let's examine this passage.

As Rumsfeld writes, the known and the unknown recognizes that information is always incomplete. Correct as far as it goes. Information is always incomplete-do we ever have all the evidence we want or need? Of course not. But was the threat of the Japanese in 1941 or Al Qaeda in 2001 an unknown unknown or even a known unknown? Evidence was ignored or underestimated-in 1941 and 2001 - not because it was "unknown," but because it didn't fit a preconceived agenda.

Both Roberta Wohlstetter and Thomas Schelling, writing for publication in the early 1960s, were concerned with the possibility of a nuclear war-how to prevent it. Wohlstetter's book ends with an admonition, not a solution: (Morris, 2013,b)

We cannot count on strategic warning. . . We must be capable of reacting repeatedly to false alarms without committing ourselves or the enemy to wage thermonuclear war. ... We have to accept the fact of uncertainty and learn to live with it. No magic, in code or otherwise, will provide certainty. Our plans must work without it. (Wohlstetter 1962, p.401) 
Morris reports on the earliest uses of the phrase "known and unknown" that he can find. The phrases appear in John Keats's Endynion (1818) and in Robert Browning' The Ring and the Book (1869). Then the phrase appears in John W. Powell's 1881. "Sketch of the Mythology of the North American Indians." John Wesley Powell, a one-armed Civil War veteran who pioneered the Grand Canyon for the government, used unknown known and the known unknown as a way to distinguish savagery from civilization. Powel wrote:

There is an unknown known; there is a known unknown. The unknown known is the philosophy of savagery; the known unknown is the philosophy of civilization. In those stages of culture that we call savagery and barbarism, all things are known - suppose to be known; but when at least something is known, understood, explained, then to those who have that knowledge in full comprehension all other things become unknown, Then is ushered in the era of investigation and discovery; the science is born; then is the beginning of civilization. The philosophy savagery is complete; the philosophy of civilization fragmentary. Ye men of science, ye wise fools, ye have discovered the law of gravity, but ye cannot tell what gravity is. But savagery has a cause and a method for all things; nothing is left unexplained. . But when the plain on which we tread becomes a portion of the surface of the great globe, and the domed firmament becomes the heavens, stretching beyond Aleyone and Sirius, With this enlargement of the realm of philosophy the verity of philosophy Is questioned. The savage is a positive man; the scientist is a doubting man. (Powell, 1881, p. 22)

It's interesting that both Powell and Rumsfeld refer to the law of gravity in their writing about the unknown known. The author's note at the opening of Rumsfeld's Memoirs is four pages devoted to discussion of the "known unknown" phrase. Rumsfeld writes, "Known knows are facts, rules and laws that we know with certainty. We know that gravity is what makes an object fall to the ground." (2011, p. xiv). Rumsfeld is preoccupied with certainty, failure of imagination and absence of evidence; Powell writes that the savage is a positive man, while the scientist is a doubting man.

In Part 3 Morris unpacks the "failure of imagination" phrase that Rumsfeld confuses with "poverty of expectations" in the forward written by Thomas Schelling for Roberta Wohlstetter's book about the Japanese bombing Pearl Harbor titled, Pearl Harbor: Warning and Decision, (dedicated "To my favorite Magician.") Rumsfeld distributed copies of Schelling's Forward to 
many government officials. Morris unravels Rumsfeld's "failure of imagination" (to predict the bombing of Pearl Harbor) as a misinterpretation of Schelling's faulting of government and bureaucratic confusion for having allowed Pearl Harbor to be bombed. Schelling and Roberta Wohlstetter fault the government; which is "always the problem," according to Mirowski's "three commandments" of neoliberalism (Mirowski, 2002, p. 203-4) for not being vigilant and allowing Pear Harbor to be sacrificed. While Rumsfeld, who works for the government, claims the bombing occurred because of a "failure of imagination" that didn't foresee the event. The discourse running through The Unknown Known seems like the discourse of someone maintaining secrets for national and job security - couldn't secrets be a kind of unknown known? If Morris obtained information for viewers about why the US went to war with Iraq, it would have been surprising, given Rumsfeld's position, neoliberal orientation and work ethics. In "A Conversation with Errol Morris" Morris claims Rumsfeld is self-deceitful and convinced of his illusions in the face of evidence that contradicts the illusions. But one might also see Rumsfeld as congruent with the mindset and work ethic of the neoliberal Chicago School economists. Rumsfeld preforms his government job in a disciplined "Chicago Tradition" style (van Horn et al. 2011; van Overtveldt, 2007, pp.19-44) and his argumentation style with the press might have been adapted from a Chicago School economics workshop (Emmett, 2011, pp.110-14). He speaks in an evasive way, which is in keeping with the Chicago School style of discourse, which entails the "capacity to absorb certain forms of criticism and thus deflect those criticisms away from the vulnerable areas in other subprograms where they might do the most damage." (Mirowski \& Hands, 1998, p. 289).

Rumsfeld is a government employee who seemingly ascribes to neoliberal ideology. Perhaps he is conflicted since being part of the government means (according to neoliberal doctrine) he is part of the problem - not the solution. And working for the Defense Department means he has to keep this contradiction a secret for national security private industry related concerns. The movie shows how Rumsfeld did his job in a Chicago School style, with "Chicago Tradition" (Van Overtveldt, 2007, pp. 19-44) work ethics, with aggressive argumentation, endless memo writing, standing for hours dictating, by arguing in abstracts, by denial, by not apologizing, by using a strategy of surprise as the appropriate response to unexpected (or unknown) events, by his confrontational management style (Rumsfeld, 2011, p. 456) and by contradicting himself. Rumsfeld contradicts himself, even at the very end of the movie where he quibbles with Morris over whether the correct phrase is the unknown, known or the known, unknown. In Machine Dreams, Mirowski unpacks the lives and theoretical work of many Cold War neoliberal OR (operations research) economists like Charles Hitch and Kenneth Arrow. While working for RAND, Arrow, like many of his fellow Chicago School economists, received a Noble Prize for economics (at least 9 Chicago School economists have received the Nobel Prize for economics) for his "impossibility theorem" (i.e. all goods are individual, there are no collective social goods), which became the foundation for social choice theory, replacing welfare economics (Marginson 2016, pp. 126-8). Mirowski points out that Arrow contradicted himself all the time (Mirowski 2002, p. 296-7).

Rumsfeld's family roots are in the Chicago area so it's not surprising Rumsfeld befriended the Chicago School's most celebrated economist, Milton Friedman, who he would ". . . turn to many times over the years for advice and guidance." (Rumsfeld 2011, p. 101). In 1976, a year after 
Rumsfeld became Gerald Ford's secretary of defense Friedman received the Noble Prize for Economics. That year Friedman was accused of being an accessory to human rights crimes because Chicago School economists restructured Chile's economy in the aftermath of the 1973 CIA assisted overthrown of democratically elected Salvador Allende. When General Augusto Pinochet took power in Chile, the so-called "Chicago Boys" a group of Chilean alumni of the University of Chicago, were tasked with implementing neoliberal reforms, in accordance with policy recommendations nicknamed "El Ladrillo" or The Brick. Chile's economy did recover - a victory for neoliberals. J. Daniel Hammond reports on this history, writing:

Anthony Lewis portrayed Friedman, who had visited Chile in the spring of 1975 with Arnold Harberger, as the "guiding light" of the Pinochet economic policy, a "policy that could not be imposed on a free society" He attributed to Friedman the idea that a growing disparity of incomes between the rich and poor is part of the mechanism by which anti-inflation policy works. Lewis asked, "if the pure Chicago economic theory can be carried out in Chile only at the price of repression should its authors feel some responsibility? There are troubling questions here about the role of academics. (Hammond, 2011, p. 36)

In 1975, the Senate Select Intelligence Committee was investigating US intelligence operations in the wake of the Watergate wiretapping scandal and President Nixon's impeachment. Senator Frank Church, who headed the commission, published fourteen reports about illegal activities by the intelligence agencies and made recommendations for reform. Morris, points out the Watergate wiretapping scandal probably alerted Rumsfeld to be careful with his record keeping. Rumsfeld seems aware of the need for secrecy when he wrote: "The best strategists try to imagine and consider the possible, even if it seems unlikely. They are then more likely to be prepared and agile enough to adjust course if and when new and surprising information requires it—when things that were previously unknown become known." (Rumsfeld, 2011, p. xiv)

RAND whistleblower Daniel Ellsberg leaked the Pentagon Papers to the New York Times in 1971, leading to the US withdrawal from Vietnam in 1975 (Stone \& Kuznick, 2013, pp.384-388). With wiretapping and scandal in the Whitehouse, the Pentagon Paper leaks ending the Vietnam War and secret RAND and the Advanced Research Project Agency (ARPA) operations in Vietnam (Project Agile and Igloo White) wiretapping the entire Ho Chi Minh Trail (Levine 2018, pp. 13-34, 26-7; Edwards, 1996, pp. 142-3) surely government contractors had reasons to be vigilant about keeping secrets for job security, as they sought another war to fill the void of Vietnam (Stone \& Kuznick 2012, pp. 395-6). And there were incentives to develop technology to reduce huge paper documents (like the Pentagon Papers) into easy to delete electronic memory that also enabled keeping track of who downloaded documents. While spy enabling 
technology improved, government employees became more secretive - or more alienated. Russ Baker documents this time period in Family of Secrets, noting:

Senator Frank Church, at least, seemed to have an inkling that

something was afoot. "there is no question in my mind," he said,

"but that concealment is the new order of the day." (Baker 2009, p. 259)

Rumsfeld published a handbook of leadership advice titled, Rumsfeld's Rules (2013). In Chapter Six, titled, The "Unknown Unknowns" Rumsfeld explains when a surprise occurs, such as an economic depression, it's easy to blame someone, rather than accept that "ours is world where uncertainty and surprise are the norm . . . One way of dealing with the likelihood of unknown unknowns is to bring a wide variety of people together and brainstorm the range of possibilities." Here is a counter to Schillings "poverty of expectations" warning. The movie and Rumsfeld's books show us how someone like Rumsfeld, or Kenneth Arrow or perhaps anyone who works in a secretive environment, but lives in a free society behaves, talks and rationalizes known unknown alienation. Such contradictions helped drive appropriation of tax dollars for a military-industrial-complex and fueled the changing mode of production as society shifted away from drafting, "snowflake" paper memos and tape-recording meetings on tapes, to an era when third party corporations keep electronic memory files on all transmitted communications and almost anything can be recorded with a cellphone.

\section{Conclusion, Observations, Questions}

In conclusion, the hypothesis discussed above is that known unknown alienation grew out of the Cold War work relations of military-industrial-complex employees who kept work related secrets for reasons of national, trade and job security. As a condition of employment, militaryindustrial-complex and telecommunications companies employees were/are expected to know certain things about work but also pretend not to know those things elsewhere - a kind of known and unknown contradiction that fosters alienation. This kind of alienation became manifest in the computerized, communications and interactive inventions of those military-industrialcomplex employees - the cell phone, the pc and the Internet. The creators of these devices have delivered to us, through these devices, infused with their known unknown alienation, a mode of production that allows both unlimited free speech, (which includes a multi-billion dollar underground on-line pornography industry) for those who wish to express it and unlimited spying capability with impunity, for spies who use the internet.

Another observation drawn from this discourse is the idea that interactive spy capable instruments that scientists made in the past, today transmit a duo or split lifestyle to us. No matter if the Internet user is a spy or someone engaged in free speech, there is an obvious split between the on-line and the off-line life experience, a contradiction that is also a driving force for capitalism; unify the split and that driving force for capitalism is changed. There is profit made in this kind of split user experience because people can't be on-line all the time, either for free speech or for spying - and yet many strive hard to unify that on-line and off-line life experience (generating hotly contested debates about possible Internet addiction) (Packard 2018a). Consider the so-called Fear of Missing Out (FOMO) disorder, where people are on-line 
habitually because they fear missing out on something. FOMO was coined by Patrick J. McGinnis, an American venture capitalist who introduced the idea of FOMO in a 2004 article in HARBUS, the student newspaper at Harvard Business School. FOMO offers an example of the contradiction of trying to be on-line all the time, while one is living in an off-line context. Spies may also have a form of FOMO because it is their job not to miss out on a target's movements; likewise video gamers, drone pilots and electronic slot machine users may try to stay on target or on-line, as long as they can; but the impossibility of unifying the on-line and off-line experience keeps the device user returning to the device. The American Cold War creators of surveillance and communication devices lived split lives too (even before the Internet existed), because they built the devices in secreted workspaces but outside of work they lived in a different, free society context (Donner 1981; Levine, 2018, pp. 23-32; Wilford 2008).

The Internet user whether a spy or not is in a state of contradiction; the spy harbors secrets, and people who make on-line pornography do too. The Internet enables the endless activity of spying, pornography or hate crimes and harboring secrets to continue, with algorithms and FOMO helping to perpetuate the pattern. Horton claims the government is in crisis because of too much secrecy - how much crisis is hidden in the Internet? This known unknown alienation has historical roots, as argued here, in the Cold War communist purging and neoliberal enterprises of the ARPA, DARPA, military-industrial-complex and private corporate network. Case study analysis could expand this discourse but what is argued here seems viable, since harboring national, trade or job security secrets is a common work experience for many employees in intelligence, the military, government, law enforcement, aeronautics, politics, the sex industry, crime, surveillance and other industries.

When Morris interviewed Rumsfeld he asked him to tell the public something about why the US went to war with Iraq after the 9/11 attacks, since the WMD supposed to be in Iraq were never found. But Rumsfeld didn't offer any new information about why the US imposed regime change on Iraq and murdered Saddam Hussein. He dismissed questions with comments about "a failure of imagination" and "an absence of evidence is not evidence of absence." When known unknown alienation seems to censor the information we seek, is it up to non-experts to use imagination and free speech to seek evidence for answers? For example, we might imagine Pearl Harbor was wittingly sacrificed by the US military, since the loss would justify building up a military-industrial-complex with lucrative contracts paid for by US dedicated GNP; Hitch and McKean wrote "sacrifices" would be have to be made for national security (Hitch \& McKean, 1965). We might imagine that WMD were not found in Iraq because Iraq's WMD were dismantled and used to implode building Seven and the Twin Towers, during 9/11. We might imagine Cold War neoliberal RAND economists planning ahead how to make money with an emerging Internet mode of production. We might imagine what well paid government spies watch on the Internet.

\section{Acknowledgements}

This is a theoretical piece to promote critical thought, inquiry and understanding about alienation and the Internet in a digital age. The author wishes to offer deepest condolences to the families of the victims of the events of March 15, 2019 in Christchurch and to the people of New Zealand. 


\section{References}

BAKER, R. (2009) Family of Secrets: The Bush Dynasty, the Powerful Forces That Put it in the White House and What Their Influence Means to America. New York, N.Y.: Bloomsbury Press.

BELL, D. \& KRISTOL, I. (1968). Confrontation: The Student Rebellion and the Universities. New York, N.Y.: Basic Books, Inc.

BRINSON, S (2004). The Red Scare, Politics, and the Federal Communications Commission, 19411960. Westport, Conn: PRAEGER.

DONNER, F. J. (1981) The Age of Surveillance: The aims and methods of America's political Intelligence system. New York: Vintage Books

EDWARDS, P.N. (1996). The Closed World: Computers and the Politics of Discourse in Cold War America. Cambridge, Mass.: The MIT Press.

EMMETT, R.B. (2011). Sharpening Tools in the Workshop: The Workshop System and the Chicago School's Success. In Building Chicago Economics: New Perspectives on the History of America's Most Powerful Economics Program (Eds. Van Horn, R., Mirowski, P., Stapleford, T. A.) (pp.93116) New York, N.Y.: Cambridge University Press.

FUCHS, C. (2016). "The Internet, Social Media and Axel Honneth' Interpretation of Georg Lukács' Theory of Reification and Alienation." In Critical Theory of Communication, pp. 153-175. London: University of Westminster Press. DOI: http;//dx.doi.org/10.16997/book1.e. License: CC-BY-NCND4.0 Retrieved 26, Jan 2019 from https://about.jstor.org/terms

FUCHS, C. (2014). Digital Labour and Karl Marx. New York, N.Y.: Routledge.

GREENWALD, G. (2014). No Place To Hide: Edward Snowden, The NSA and the U.S. Surveillance State. New York, N.Y.: Metropolitan Books.

HALPERIN, M. H., BERMAN, J.J., BOROSAGE, R.L. \& MARWICK, C.M.(1976). The Lawless State: The Crimes of the U.S. Intelligence Agencies. Penguin Books.

HARRIS, S. (2014). @War: The Rise of the Military-Internet Complex. New York, N.Y: Houghton, Mifflin Harcourt.

HARRIS, S. (2010). The Watchers: The Rise of America's Surveillance State. New York, N.Y.: Penguin Press.

HARVEY, D. (2005). A Brief History of Neoliberalism. New York, N.Y.: Oxford University Press.

HAMMOND, D.J. (2011). Markets, Politics, and Democracy at Chicago: Taking Economics Seriously. In Building Chicago Economics: New Perspectives on the History of America's Most Powerful Economics Program (Eds. Van Horn, R., Mirowski, P., Stapleford, T. A.) (pp. 36-66) New York, N.Y.: Cambridge University Press.

HITCH, C. J. \& McKEAN, R.N. (1965) The Economics of Defense in the Nuclear Age.With contributions from, Enke, S., Enthoven, A., Hoag, M., McGuire, C.B., and Wohlstetter, A. New York, N.Y.: Atheneum, 
HORTON, S. (2015) Lords of Secrecy: The National Security Elite and America's Stealth Warfare. New York N.Y.: Nation Books.

JACOBSEN, A. (2015). The Pentagon's Brain; An Uncensored History of DARPA America's Top Secret Military Research Agency. New York, N.Y.: Black Bay Books

JAEGGI, R. (2014). Alienation. New York, N.Y.: Columbia University Press. Retrieved 27-01-19 from https://about.jstor.org

LANE III, F. S. (2000). Obscene Profits: The Entrepreneurs of Pornography in the Cyber Age. New York, N.Y: Routledge

LEESON, R. (Ed.) (2008). The Anti-Keynesian Tradition. Great Britain: Palgrave

LEESON, R. (2000). The Eclipse of Keynesianism: The Political Economy of the Chicago CounterRevolution. Great Britain: Palgrave

LEVINE, Y. (2018). Surveillance Valley: The Secret Military History of the Internet. New York, N.Y: Public Affairs.

MARGINSON, S. (2016). The Dream is Over: The Crisis of Clark Kerr's California Idea of Higher Education. Oakland, CA.: University of California Press. DOI: http://doi. Org/10.1525/luminous.17 Retrieved from University of Auckland library 11 February, 2019.

MARX, K. (1990/1867). Capital: A critique of political economy, Volume I. Translated by Ben Fowkes. London: Penguin Classics.

MARX, K., (1978). "Economic and Philosophic Manuscripts of 1844". In The Marx-Engels Reader (2nd Ed) Ed. Tucker, R. New York: W.W. Norton \& Co. pp.66-125.

MIROWSKI, P. (2002). Machine Dreams: Economics Becomes a Cyborg Science. N.Y., N.Y.: Cambridge University Press.

MIROWSKI, P. \& HANDS, W. (1998) "A Paradox of Budgets: The Postwar Stabilization of American Neoclassical Demand Theory." In From Interwar Pluralism to Postwar Neoclassicism. Annual Supplement to Volume 30 History of Political Economy (eds. Morgan, M.S. \& Rutherford) M. Durham: Duke University Press,

MORGAN, M.S. \& RUTHERFORD, M. (Eds.) (1998). From Interwar Pluralismto Postwar Neoclassicism. Annual Supplement to Volume 30 History of Political Economy. Durham: Duke University Press.

MORRIS, E. (Prod. \& Dir.) (2013a), Fernandez, R. \& Branson Gill, A. (Prod.). (2013) The Unknown Known. [DVD]. USA; History; participant \& RADIUS TWC

MORRIS, E. (Author, Producer, Dir) (2013b). Four Part Op-ed "The Certaintyof Donald Rumsfeld" by Errol Morris. Special Bonus Feature of The Unknown Known [DVD]. USA; History; participant \& RADIUS TWC

MURRAY, R. K. (1955). Red Scare: A Study in National Hysteria, 1919-1920. New York, N.Y: McGraw-Hill. 
NORBERG, A. \& O'NEILL, J. (1996) Transforming Computer Technology: Information Processing for the Pentagon 1962-1986. London, U.K: The John Hopkins Press, Ltd.

PACKARD, N. (2018a) Habitual Interaction Estranged International Journal of Social Sciences, Vol. VII (1) (pp. 69-94), 10.20472/SS.2018.7.1.005

PHILLIPS, P. (2018). GIANTS: The Global Power Elite. Oakland, CA: Seven Stories Press.

POWELL, J.W. (1881). "Sketch of the Mythology of the North American Indians." In the First Annual Report of the Bureau of Ethnology to the Secretary of the Smithsonian Institution.

ROHDE, J. (2013). Armed with Expertise: The Militarization of American Social Research, During the Cold War. Cornell, N.Y.: Cornell University Press.

ROSENFELD, S. (2013). Subversives: The FBI's War on student radicals and Reagan's rise to power. New York: Farrar, Straus, and Giroux.

RUMSFELD, D. (2011). Known and Unknown: A Memoir. New York, N.Y.: Sentinel.

RUMSFELD, D. (2013). The Unknown Unkowns in Rumsfeld's Rules New York, N.Y.: Broadside Books. Retrieved 21-01-19 from hhtps://www.safaribooksonline.c

SCHELLING, T. (1962). Forward. In Wohlstetter, R. Pearl Harbor: Warning and Decision. Stanford, CA: Stanford University Press.

SHILS, E. A. (1956). The Torment of Secrecy: The Background and Consequences of American Security Policies. London, Great Britain: William Heinemann Ltd.

SCHLOSSER, E. (2013). Command and Control: Nuclear Weapons, theDamascus Accident and the Illusion of Safety. New York, N.Y.: Penguin Press

SHORROCK, T. (2008). Spies for Hire: The Secret World of Intelligence Outsourcing. New York, N.Y.: Simon \& Schuster.

SKLAIR, L. (2001) The Transnational Capitalist Class. Malden, Mass.: Blackwell

STONE, O. \& KUZNICK, P. (2013) The Untold History of the United States. US: Ebury.

STORRS, L.R.Y. (2013) The Second Red Scare and the Unmaking of the New Deal Left. Princeton, N.J.: Princeton University Press.

VAN HORN, R., MIROWSKI, P., STAPLEFORD, T. A. (Eds.) (2011). Building Chicago Economics: New Perspectives on the History of America's Most Powerful Economics Program. New York, N.Y.: Cambridge University Press.

VAN OVERTVELDT, J. (2007). The Chicago School: How the University of Chicago Assembled the Thinkers Who Revolutionized Economics and Business. Chicago, II: AGATE.

WILFORD, H. (2008). The Mighty Wurlitzer: How the CIA Played America. Cambridge, Mass.: Harvard University Press

WOHLSTETTER, R. (1962). Pearl Harbor: Warning and Decision. Stanford, CA: Stanford University Press. 
ZUBOFF, S. (2019). The Age of Surveillance Capitalism: the Fight for a Human Future at the New Frontier of Power USA: Profile Books. 